\title{
BREVÍSSIMAS NOTAS PÓSTUMAS EM HOMENAGEM AO PROFESSOR DOUTOR R. LIMONGI FRANÇA
}

\section{Flávio Marcondes Velloso*}

O insigne mestre Rubens Limongi França nasce em Guaratinguetá aos 15 de outubro de 1927. Era, pois, no Dia do Professor e talvez, não por mera coincidência, já predestinado a ser um dos grandes vultos das Arcadas...

De labuta incansável, o professor Limongi França vem a receber, dentre tantas e inúmeras láureas acadêmicas, intelectuais e honoríficas, conquistadas sem exceção por seu invulgar brilho e merecimento, a de titular da Faculdade de Direito da Universidade de São Paulo, onde ensina a centenas e mais centenas daqueles que carregariam o privilégio e a marca de suas lições, dentre esses, v. g., o ministro, até recentemente presidente do Supremo Tribunal Federal, José Celso de Mello Filho, seu afilhado.

Conferencista nacional e internacional, professor honorário das melhores universidades européias e americanas, das escolas superiores de magistratura e de advocacia, membro titular da Academia Brasileira de Letras Jurídicas, medalha Ruy Barbosa conferida pelo presidente da República, medalha Comenius pela Academia Cristã de Letras, medalha Anchieta pela Municipalidade de São Paulo, medalha de Ouro do Mérito Jurídico Civil pelo Instituto para a Divulgação do Direito Civil, sócio de honra do Instituto dos Advogados, do Instituto de Direito de Autor e fundador do Instituto de Direito Comparado Luso-Brasileiro.

Referência clássica, universal e segura do melhor Direito e da melhor doutrina, na qualidade incomum de professor e autor de obra profunda e vasta, com mais de três centenas de livros publicados, todos de incontestável reconhecimento, sem descuidar, contudo, das horas dedicadas à poesia, às letras e à espiritualidade como, por exemplo, os seus escritos que vão de Castro Alves à cromoterapia e à cura pelas mãos...

* Flávio Marcondes Velloso, autor de "Ensaios Juridicos. Temas Inéditos" e de "Tribunal Internacional de Justiça. Caminho para uma nova comunidade", esse último, a ser lançado na Feira de Frankfurt. Alemanha, exatamente na semana do aniversário de nascimento do professor e a ele dedicado. 
No campo juridico, a sua incomparável Enciclopédia do Direito, a maior edição brasileira de todos os tempos, com 78 volumes, dá-lhe a fama justa, para além dos seus conhecidos atributos e virtudes, de "executivo do Direito" por seus pares que nela colaboraram, como é o caso do professor Goffredo da Silva Telles Junior, o qual publica presentemente a sua Folha Dobrada, em que presta, às páginas 900 e 901, a sua consideração ao labor do grande Limongi França, confessando ter dele transformado em quadro uma sua missiva, para tomar sempre dela inspiração...

$\hat{E}$ bem de mencionar ainda as suas consagradas Instituições de Direito Civil" onde consegue o feito de versar, com a propriedade, o rigor e o domínio de sua cultura, todo o Direito Civil em um só volume, em pouco mais de mil páginas. Mas a sua genialidade transborda e cria também nas artes, sendo de suas cores mais de cem telas e de suas talhas mais de trinta esculturas, várias retratando a sua gente, as suas origens nas terras do presidente-conselheiro Francisco de Paula Rodrigues Alves e do frei Antônio de Sant'Anna Galvão, nascido Antônio Galvão de França, como a festejada pintura de "O Sapateiro"...

De sua "joie de vivre" como humanista e alma sensível deixa, de vários casamentos, a sua incomensurável e ainda maior riqueza na forma de Ana Isabel, Ana Cristina, Antônio de Sant'Anna, Ana Carlota, Vicente de Paula, Ana Juditte, Carlos Otávio, filhos, e Caio Augusto, Ana Alice, Manoel, João Mário, Pedro, Maria Júlia e Eduardo, netos, os quais, à beira de seu túmulo, em fala uníssona e geral confessam naquele momento experimentar e descobrir "mais uma vez a força da sua presença, o significado do seu jeito intenso, assertivo e batalhador de ser em tantas atividades e expressões' externando-lhe perene gratidão...

E aqui rogamos vênia para consignar a nossa, com declarada admiração e profundo respeito ao dileto mestre e amigo professor doutor Rubens Limongi França que, aos 18 de setembro do presente ano, de maneira inesperada, segue, livre, para a frente e para o alto, de encontro ao Mestre dos mestres, perante a Divina e Eterna Obra do Pai. Como alguém disse alhures, "il a bien mérité la patrie"... Soube, como poucos o sabem, elevar o nome de sua cidade natal, de sua Faculdade e de seu país.

Primavera de 1999. 


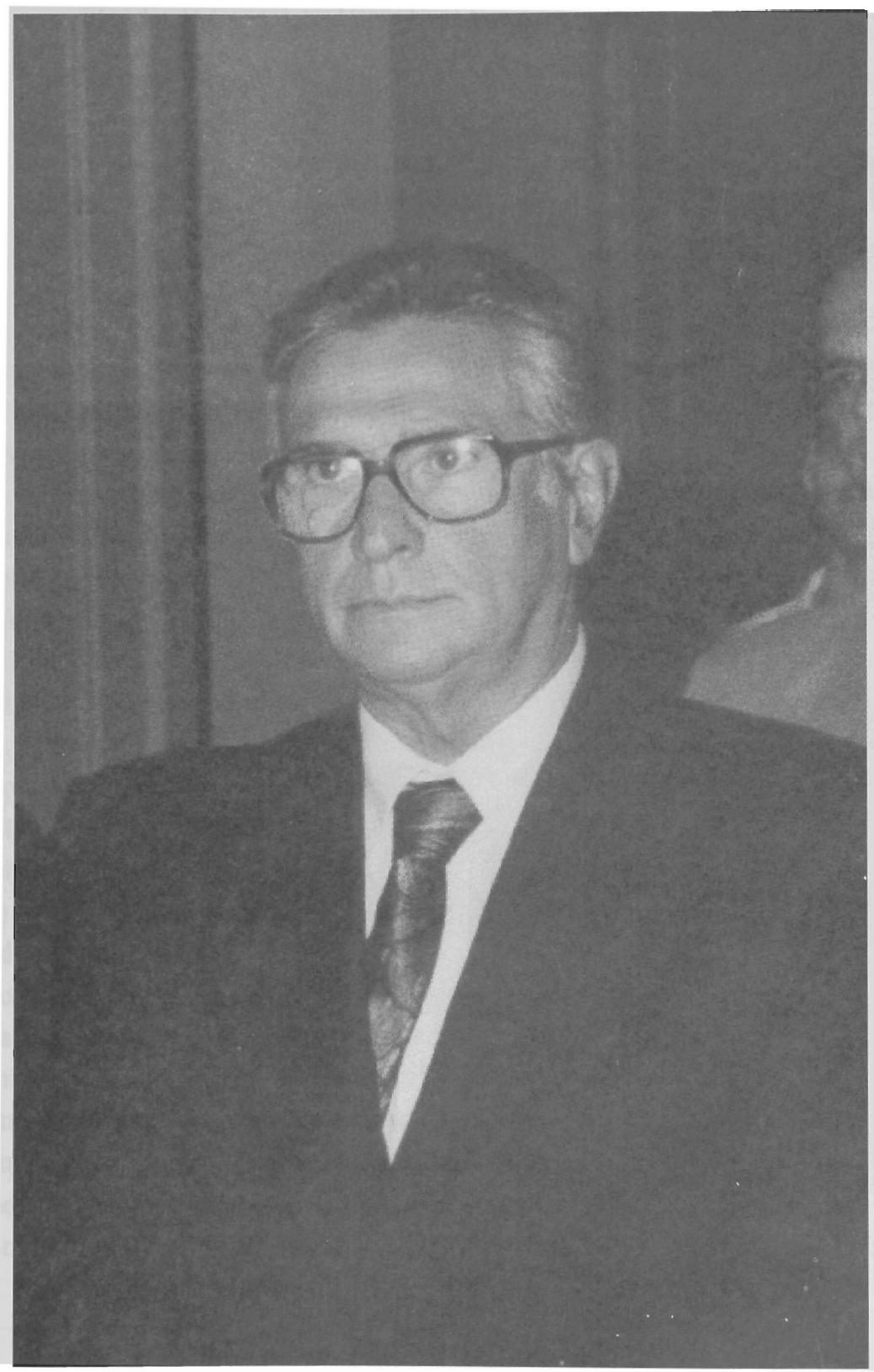

Professor Doutor Rubens Limongi França 